\title{
Partial purification and characterization of a novel murine factor that augments the expression of class I MHC antigens on tumor cells
}

\author{
Niti Puri and R. K. Saxena \\ School of Life Sciences, Jawaharlal Nehru University, \\ New Delhi 110067, India \\ Accepted 28 May 1998
}

Abbreviations: MHC, major histocompatibility complex; MHC-AF, MHC-augmenting factor; VSV, vesicular stomatitis virus; IFN, interferon; TCR, T cell receptor; NK, natural killer; TFA, trifluoroacetic acid; MLR, mixed lymphocyte reaction

\begin{abstract}
A soluble factor which augments the expression of major histocompatibility complex class I (MHC I) antigens on a number of murine tumor cell lines, has been isolated from the culture supernatants of mixed lymphocyte reaction of spleen cells derived from C57BI/6, Balb/c and Swiss mice. The factor, termed MHC-augmenting factor (MHC-AF) has been partially purified by Sephadex G-100 column chromatography and reverse phase HPLC. MHC-AF activity is associated with an $18 \mathrm{kDa}$ molecule. MHC-AF activity was resistant to $\mathrm{pH} 2.0$ treatment and partially purified MHC-AF preparations did not have any activity in L929 cell/vesicular stomatitis virus (VSV) interferon bioassay system. Antibodies to IFN- $\gamma$ did not block the activity of MHC-AF. These results indicate that a MHC-AF distinct from IFN- $\gamma$, is produced by mouse spleen cells undergoing a mixed lymphocyte reaction.
\end{abstract}

Keywords: MHC class I, IFN- $\gamma$, MHC-AF, Tumor cells, Cytokines

\section{Introduction}

Highly polymorphic majot histocompatibility complex (MHC) locus codes for Class I and II molecules which play a central role in immune cell interactions. MHC class I and II molecules present antigen derived peptides to $\mathrm{CD}^{+}$ and $\mathrm{CD}^{+}$subset of T-lymphocytes respectvely (Benham et al., 1995). In addition, antigen receptors on T-cells (TCR) can recognize antigenic peptides only when the latter is presented in association with self $\mathrm{MHC}$ molecules, a phenomenon referred to as $\mathrm{MHC}$ restriction (Zinkernagel and Doherty. 1979). Natural Killer (NK) cells constitute a non-T-non-B class of lymphocytes which spontaneously kill target cells in a MHC nonrestricted manner. Alterations in the expression levels of class I MHC antigens on target cells nonetheless regulates their susceptiblity to NK cell mediated lysis. An inverse correlation between the NK sensitivity of target cells and their levels of expression of class I MHC antigen has reported in many systems (Harel-Bellan et al., 1986; Karre et al., 1986, Kawano et al., 1986). Both NK and T cells participate in antitumor immunesurveillance mechanisms and since the class I MHC expression on the tumor cells determines their susceptiblity to these immunesurveillance mechanisms, factors which regulate the expression of the class I MHC antigens on tumor cells, may play an important role in determining the fate of a tumor in vivo.

Many factors are known to modulate class I MHC antigen expression on tumor cells. These include cytokines such as interferon (IFN) (Rosa and Fellows 1984; Taniguchi et al., 1987; Reiter et al., 1988), in vivo passage of tumor cells (Piontek et al., 1985) and inducers of differentiation, such as phorbol esters and sodium butyrate (Stern et al., 1980; Gidlund et al., 1981). We have previously shown that culture supernatants of Con A activated rat spleen cells contain a soluble factor distinct from IFN- $\gamma$, which upregulates the expression of class I MHC antigens on some tumor cell lines (Saxena et al., 1988a, 1989). Since Con A itself induces the expression of class I MHC antigens on tumor cells, the possibility remains that the MHC augmenting factor detected in Con A activated culture supernatants was derived from Con $A$ itself. We therefore tried to use mixed lymphocyte reaction (MLR) as a means of activation of spleen cells in order to avoid Con A. In the present study, we have shown that murine MLR culture supernatants contain a soluble factor similar to that described in rat spleen Con A supernatants. We have partially purified and characterized this activity.

\section{Materials and Methods}

\section{Animals}

Inbred $\mathrm{C} 57 \mathrm{BI} / 6$ and $\mathrm{Balb} / \mathrm{c}$ and outbred Swiss albino mice (8-12 weeks) were used throughout this study. All animals were bred and maintained in the Animal House Facility in Jawaharlal Nehru University, New Delhi.

\section{Culture medium}

Tumor cell lines were maintained in RPMI-1640 supplemented with $5 \%$ fetal calf serum, $60 \mu \mathrm{g} / \mathrm{ml}$ gentamicin 
(complete medium). The complete media used for generation of MLR culture supernatant were either RPMI-1640 from Sigma supplemented with $2 \%$ fetal calf serum, $2 \times$ $10^{-5} \mathrm{M}$ mercaptoethanol, $300 \mu \mathrm{g} / \mathrm{ml}$ gultamine and 60 $\mu \mathrm{g} / \mathrm{ml}$ gentamicin (Complete medium or $\mathrm{CM}$ ), or serum free DCCM-2 medium (Biological Industries, Israel) supplemented with $2 \times 10^{-5} \mathrm{M}$ 2-mercaptoethanol, 300 $\mu \mathrm{g} / \mathrm{ml}$ gultamine and $60 \mu \mathrm{g} / \mathrm{ml}$ gentamicin (Serum free Complete Medium, SF-CM).

\section{Monoclonal antibodies and antibody conjugates}

Supernatants from hybridoma cell lines HB102 (secreting anti-H-2D ${ }^{\mathrm{d}}$ ), HB170 (secreting anti-IFN $\gamma$ ), B468 (secreting anti- $\mathrm{H}-2 \mathrm{~K}^{\mathrm{k}}$ ) and $\mathrm{B} 896$ (secreting anti- $\mathrm{H}-2 \mathrm{~K}^{\mathrm{b}}$ ) were used as a source of monoclonal antibodies. Rabbit antimouse Ig-HRPO conjugate (from Sigma) was used as second antibody in the tube ELISA. Rabbit anti-mouse Ig-FITC from Sigma or Goat anti-mouse Ig-mouse IgFITC from Gibco BRL were used as second antibody in flow-cytmetric studies.

\section{Tumor cell lines}

Murine cell lines YAC (ATCC, TIB160), EL-4 (ATCC, TIB 39) and BW5147 (ATC, TIB47) all T-cell lymphomas, and L929 (ATCC, CCLI) fibroblast cell line, were originally obtained ATCC. All these lines were maintained and propagated by serial transfers in complete medium.

\section{Estimation of cell surface antigens on tumor cell lines}

The cell surface antigens on tumor cell lines were estimated by using a modifies cell ELISA technique or by flowcytometry as described elsewhere (Sarin and Saxena 1990). Briefly, for ELISA based estimation, cells were incubated with $200 \mu \mathrm{l}$ of anti-MHC monoclonal antibody on ice for 30 minutes and washed twice with PBS. Appropriately diluted second antibody $(0.2 \mathrm{ml})$ was added to the cells and the incubation on ice continued for $45 \mathrm{~min}$. At the end of this incubation, cells were washed three times and color developed at $37^{\circ} \mathrm{C}$ by adding $0.5 \mathrm{ml}$ of substrate solution $(0.5 \%$ orthophenylene diamine in 0.1 $\mathrm{M}$ citrate phosphate buffer $\mathrm{pH} 5.2$, and $10 \mu \mathrm{l}$ of $30 \%$ $\mathrm{H}_{2} \mathrm{O}_{2}$ ). The enzyme reaction was quenched by adding $0.1 \mathrm{ml} 5 \mathrm{~N} \mathrm{H}_{2} \mathrm{SO}_{4}$ per tube and color read at $492 \mathrm{~nm}$ using an ELISA microplate reader. For flowcytometric studies, tumor cells were suspended in $50 \mu$ of required hybridoma culture supernatants and incubated for 20 min at $4^{\circ} \mathrm{C}$. Cells were washed once with cold PBS and suspended in $50 \mu \mathrm{l}$ of the appropriate dilution of the second antibody-FITC conjugate. After 20 min incubation at $4^{\circ} \mathrm{C}$, cells were washed and fixed in $1 \mathrm{ml}$ of $1 \%(\mathrm{w} / \mathrm{v})$ paraformal-dehyde in PBS. Stained and fixed cells were analyzed on a flow cytometer (Coulter-EPICS-XL model).

\section{IFN bioassay}

Bioassay for antiviral activity of IFN was carried out using L929/VSV system as described earlier (Saxena et al., $1988 b)$. One unit of interferon corresponded to half protection of L929 cells.

\section{Preparation of mouse MHC-AF}

Spleen cells ( 5 million cells $/ \mathrm{ml}$ ) from Balb/c or C57BI/6 mice were cultured with spleen cells from Swiss mice in RPMI-1640 medium containing $2 \%$ FCS or in DCCM-2 serum free medium. After 5 days MLR culture supernatants were harvested and precipitated by adding ammonium sulphate $\left(85 \%\right.$ saturation, overnight at $\left.4^{\circ} \mathrm{C}\right)$. Precipitated proteins were dissolved in deionized water, dialyzed two changes of $0.1 \mathrm{M}$ glycine- $\mathrm{HCl}$ buffer $\mathrm{pH} 2.0$ followed by two change of PBS and concentrated on Amicon $3 \mathrm{~K}$ membrane filter to about $30 \mathrm{ml}$ for each liter of the starting material. Protein estimations were done by the method of Bradford (1976).

\section{Sephadex G-100 column chromatography}

$10 \mathrm{ml}$ of the crude MHC-AF concentrate was fractionated on a Sephadex G-100 column $(25 \times 600 \mathrm{~mm})$. The column was run at $4^{\circ} \mathrm{C}$ at a flow rate of $35 \mathrm{ml}$ per hour in PBS and $10 \mathrm{ml}$ fractions collected. Fractions with $\mathrm{MHC}-\mathrm{AF}$ activity were polled and concentrated using Amicon $3 \mathrm{~K}$ membrane filters.

\section{High performance liquid chromatography (HPLC)}

The post Sephadex G-100 MHC-AF preparation was dialyzed against water, reconstituted with $0.1 \%$ trifluoroacetic acid (TFA) and and fractionated on a Delta Pak C18 reverse phase column $(3.9 \mathrm{~mm} \times 150 \mathrm{~mm})$ from Waters. The elution solvents were $0.1 \%$ TFA (SolventA) and $80 \%$ acetonitrile containing $0.1 \%$ TFA (Solvent$B)$. The reverse phase column was eluted with a linear gradient of $1-100 \%$ solvent-B in $40 \mathrm{~min}$. The fractions of reverse phase run were lyophilized, redissolved in PBS, and assayed for MHC-AF activity.

\section{2-D Gel electrophoresis}

2-D-gel electrophoresis of MHC-AF was carried out on Mighty small gel apparatus from Hoefer, according to the manufacturer's instructions.

\section{Results} Upregulation of MHC class I antigen expression
by MLR supernatants

Mouse spleen cells were activated in a mixed lymphocyte 


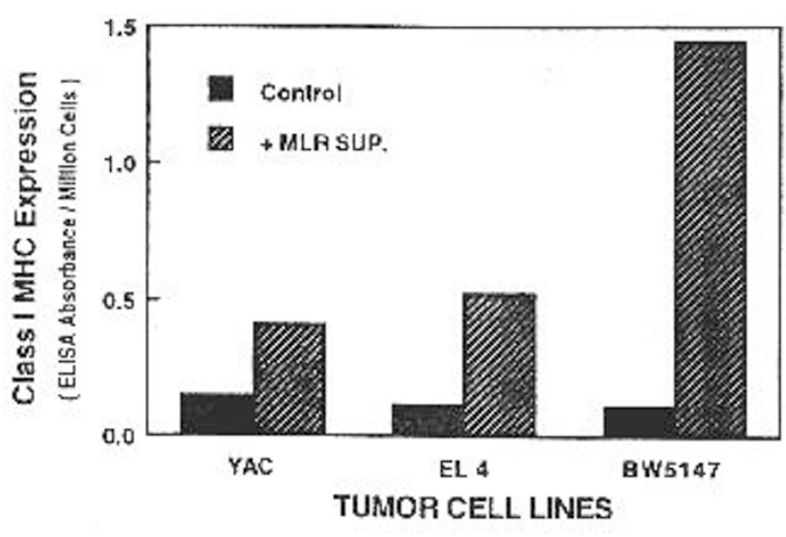

Figure 1. Augmentation of class I MHC expression on various murine tumor cell lines by allogenic MLR supernatants. YAC, EL-4 and BW5147 cells were seeded in culture at $2 \times 10^{5}$ cells $/ \mathrm{ml}$ with or without $20 \%$ Swiss vs C57BI/6 MLR supernatant, which was pre-dialyzed against $0.1 \mathrm{M}$ glycine- $\mathrm{HCl}$ buffer $(\mathrm{pH} 2.0)$, to deactivate any IFN- $\gamma$. On day 2 , the cells were harvested and their class I MHN expression studied by the cell ELISA technique.

reaction and the culture supernatants harvested on day 5 were dialyzed against $\mathrm{pH} 2.0$ to deactivate any IFN- $\gamma$, and checked for their effect on the expression of class I $\mathrm{MHC}$ antigens on different tumor cell lines. Results in Figure 1 show that MLR supernatants caused a marked increase in the expression of class I MHC antigens on YAC, EL-4 and BW5147 cell lines. This biological activity was termed $\mathrm{MHC}$ augmenting factor or MHC-AF. Partially purified preparations of MHC-AF were derived from MLR supernatants by ammonium sulfate precipitation (85\% saturation) followed by fractionation on Sephadex G100 column. Elution profile of MHC-AF on Sephadex G100 column is shown in Figure 2A. From the positions of elution of marker proteins from the Sephadex column the molecular weight of MHC-AF appears to be approximately $18 \mathrm{kDa}$. The fractions with $\mathrm{MHC}-\mathrm{AF}$ activity were pooled and concentrated using an Amicon $5 \mathrm{~K}$ cut off membrane, to the origonal loading volume. This preparation was used as MHC-AF in the experiments that follow. As a control, RPMI-1640 medium (with $2 \%$ FCS) was also fractionated on a Sephadex G-100 column, but in this case, none of the column fractions showed any MHC-AF activity (Figure 2B).

Results in Figure $3 \mathrm{~A}$ show that MHC-AF induced a dose-dependent increase in the expression of class I MHC antigens on YAC and BW5147 tumor cell lines. There was a concomitant decline in viable cell numbers in the cultures treated with MHC-AF. A time kinetic of MHC-AF effcet is shown in Figure 3B. These results showed that MHC-AF induced significant increase in the class I MHC expression of YAC, after $12 \mathrm{~h}$ of treatment.

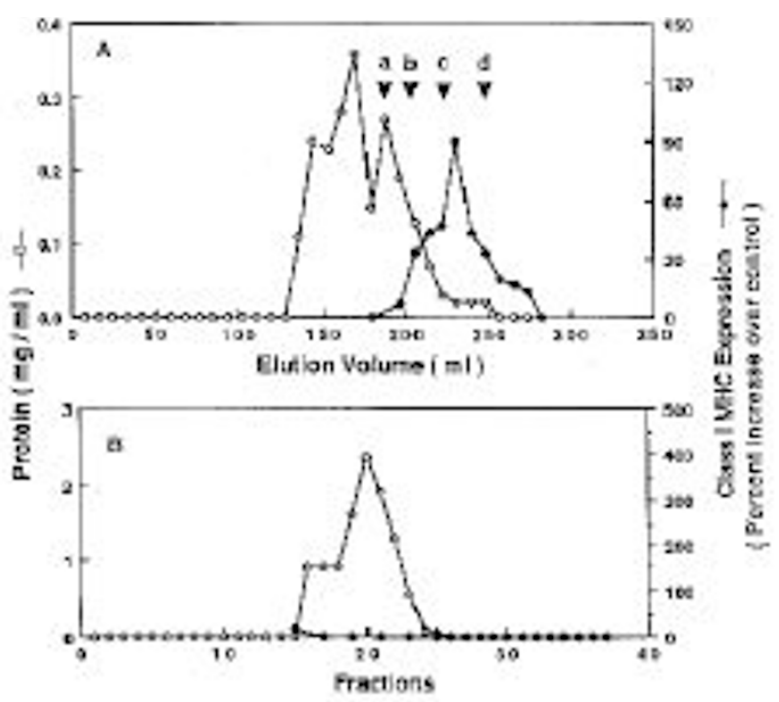

Figure 2. The elution profiles of MHC-AF on a Sephadex G-100 column. Crude MHCAF preparations obtained after ammonium sulfate precipitation and dialysis against glycine-HC1 buffer, $\mathrm{pH} 2.0$ of culture supernatants from Swiss vs C57B1/6 MLR, generated in RPMI- 1640 containing $2 \%$ fatal calf serum $(A)$, were loaded on a Sephadex G-100 column $(25 \times 600 \mathrm{~mm})$. The MHC-AF activity in each fraction was assayed by culturing YAC cells with different fractions at $25 \%(\mathrm{~V} / \mathrm{v})$ concentration for 48 h. The class I MHC expression on these YAC cells was then determined by cell ELISA technique/ Flowcytometry described in 'Materials and Methods'. The Sephadex G-100 column (A) was calibrated for molecular weight determination using bovine serum albumin $A(a)$, ovalbumin (b), chymotrypsinogen $A(c)$ and ribonuclease $A(d)$. The position of elution of each marker is designated by an arrow. As a control, RPMI-1640 ( $2 \%$ fatal calf serum) medium was also processed similarly and loaded on a Sephadex G-100 column. Panel B shows the elution profile of this medium control. Protein $(\bigcirc)$ and MHC-AF ( ) activity profiles for each run have been shown.

Maximum increase was seen after $48 \mathrm{~h}$ of culture with MHC-AF.

\section{Relationship between MHC-AF and IFN- $\gamma$}

IFN- $\gamma$ was present in fresh MLR supernatants, but dialysis of MLR supernatants against $0.1 \mathrm{M}$ glycine- $\mathrm{HCl}$ buffer $\mathrm{pH}-2.0$ for $48 \mathrm{~h}$ abrogated all antiviral activity (Table 1 ). These results indicate that all IFN activity in MLR supernatants was due to IFN- $\gamma$ which is $\mathrm{pH} 2.0$ labile, all other species of IFN being pH 2.0 stable. MHC-AF preparations were routinely dialyzed against $\mathrm{pH} 2.0$ buffer and were devoid of any antiviral activity indicating the absence of biologically active IFN in these preparations.

\section{Comparsion of potencies of MHC-AF and IFN- $\gamma$}

IFN- $\gamma$ and MHC-AF preparations were tested at different doses to assess their relative potencies in augmenting class I MHC antigen expression on YAC and EL-4 tumor cells. IFN- $\gamma$ induced a maximum 2 to 2.5 fold increase in class I MHC antigen expression on YAC cells 


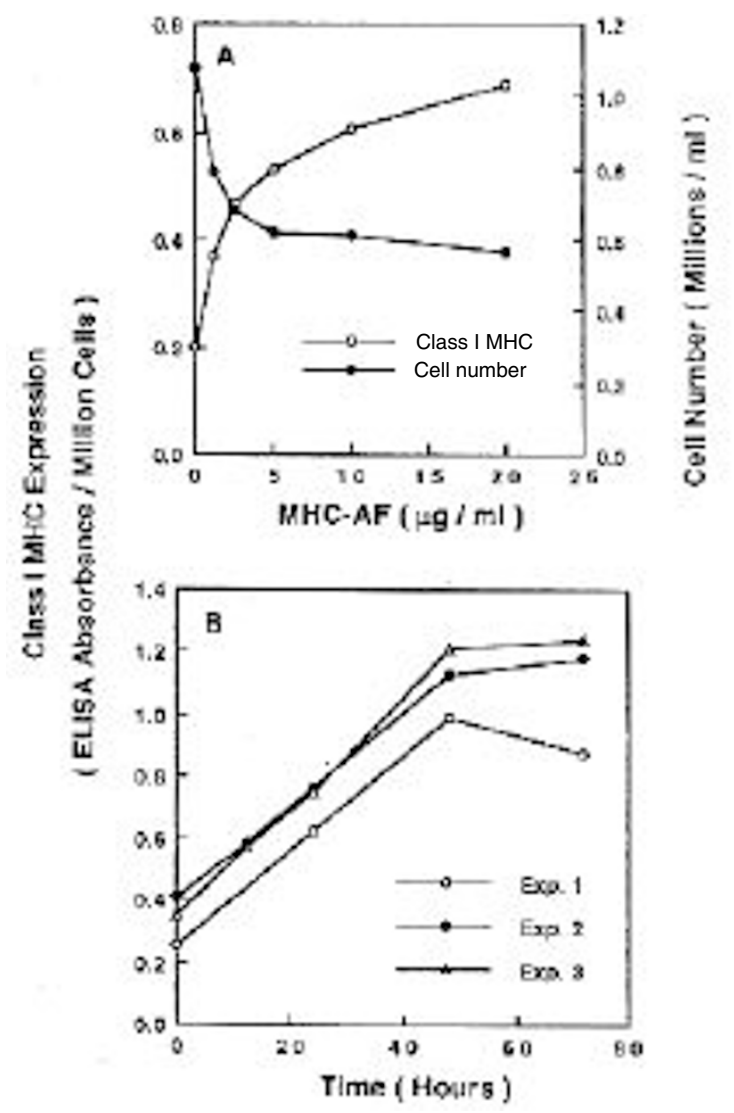

Figure 3. Panel-A Dose response of MHC-AF on class I MHC antigen expression and cell number of YAC tumor cell line. YAC cells were cultured at $2 \times 10^{5}$ cells $/ \mathrm{ml}$ with different doses of MHC-AF. After $48 \mathrm{~h}$, the cells were harvested, counted $(\mathcal{O})$ using the vital dye trypan blue and their class I MHC expression $(\bigcirc)$ studied by cell ELISA technique. Panel-B: Time kinetics of modulation of class I MHC expression on YAC by MHC-AF. YAC cells were cultured at $2 \times 10^{5}$ cells $/ \mathrm{ml}$ in complete medium for $72 \mathrm{~h}$. During incubation MHC-AF ( $20 \mu \mathrm{g} / \mathrm{ml}$ of a post Sephadex G-100 MHC-AF preparation) was added to the YAC cells at different time points, so that the exposure of different YAC cultures to MUC-AF at the end of the culture was $12,24,48$ or $72 \mathrm{~h}$. Class I MHC expression of different YAC cell preparation was determined by the cell ELISA techniclue. Results of three experiments are shown. at a concen-tration of about $100 \mathrm{U} / \mathrm{ml}$ (Figure 4). MHC$\mathrm{AF}$ induced increase in class I MHC antigen expression (upto 4 fold) was significantly greater than the effect of IFN- $\gamma$.

\section{Lack of neutralization of MHC-AF activity by anti IFN antibodies}

In order to further confirm MHC-AF as an entity distinct from IFN, the effect of anti-mouse IFN- $\gamma$ antibodies, on MHC-AF activity was studied. Results in Figure 5 showed that anti IFN- $\gamma$ antibody preparation could neutralize the effect of IFN- $\gamma$ on upregulation of class I MHC antigen expression on YAC, but this reagent could not block the effects of MHC-AF.

\section{Effect of Heat treatment on MHC-AF activity}

In order to assess whether MHC-AF is a macromolecule susceptible to heat denaturation, MHC-AF preparations

Table 1. Loss of IFN- $\gamma$ activity in MHC-AF preparation by $\mathrm{pH} 2.0$ dialysis.

\begin{tabular}{lc}
\hline $\begin{array}{c}\text { Treatment } \\
\text { of L929 cells }\end{array}$ & Protection of L929 \\
\hline IFN- $\gamma(3 \mathrm{U})$ & ++++ \\
IFN- $\gamma(1 \mathrm{U})$ & ++++ \\
IFN- $\gamma(0.3 \mathrm{U})$ & ++++ \\
IFN- $\gamma(0.1 \mathrm{U})$ & ++ \\
Undialysed MHC-AF $(1: 10)$ & ++++ \\
pH 2.0 dialysed MHC-AF $(1: 10)$ & + \\
\hline
\end{tabular}

(L929 cells $3 \times 10^{4} /$ well) were seeded in a 96 well flat bottom microtiter plate with or without indicated doses of IFN- $\gamma$. L929 cells were also cultured in the presence of one undialysed preparation of MHC-AF and the same MHC-AF preparation after a $48 \mathrm{~h}$ dialysis against glycine $\mathrm{HCl}$ buffer ( $\mathrm{pH}$ 2.0). After monolayers of $\mathrm{L} 929$ were formed, 10 $\mu$ of appropriately diluted VSV was added per well. After another $48 \mathrm{~h}$, cytopathic effect of virus was assessed microscopically. ++++ denotes complete protection of the L929-cells and zero denotes no protection.

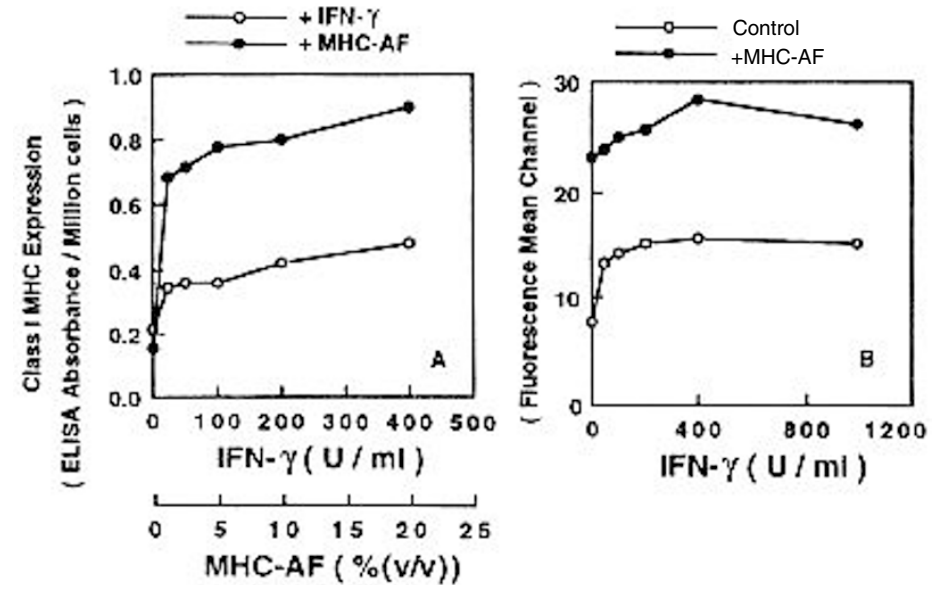

Figure 4. Panel A: Comparison of effect of IFN- $\gamma$ and MHC-AF on class I MHC expression of tumor cell lines. YAC cells were cultured with different doses of IFN- $\gamma$ or MHC-AF for $48 \mathrm{~h}$. The class $1 \mathrm{MHC}$ antigen levels were estimated by cell ELISA. Panel B: Effect of different doses of IFN- $\gamma$ alone or in combination with MHC-AF on class I MHC expression of EL-4, has been shown. EL-4 cells were cultured with combinations of different doses of IFN- $\gamma$ with or without MHC-AF $(20 \%, v / v)$ for $48 \mathrm{~h}$. The class I MHC antigen levels were estimated by using flowcytometer, as described in the 'Materials and Methods'. 
Table 2. Deactivation of MHC-AF activity by Trypsin and Chymotrypsin treatment.

\begin{tabular}{lcc}
\hline $\begin{array}{l}\text { Treatment of } \\
\text { YAC cells }\end{array}$ & \multicolumn{2}{c}{$\begin{array}{l}\text { Class I MHC expression on YAC } \\
\text { (ELISA Absorbance/million cells) }\end{array}$} \\
\hline & Experiment 1 & Experiment 2 \\
\hline $\begin{array}{l}\text { PBS control } \\
\text { PBS treated with }\end{array}$ & 0.4550 & 0.6657 \\
$\begin{array}{l}\text { Trypsin beads } \\
\text { MHC-AF }\end{array}$ & 0.4394 & 0.6400 \\
MHC-AF treated with & 0.7762 & 1.3319 \\
Trypsin beads & 0.3930 & 0.8005 \\
\hline $\begin{array}{l}\text { PBS control } \\
\text { PBS treated with }\end{array}$ & 0.6657 & 0.3334 \\
Chymotrypsin beads & 0.6400 & 0.3136 \\
$\begin{array}{l}\text { MHC-AF } \\
\text { MHC-AF treated with }\end{array}$ & 1.3319 & 0.9506 \\
Chymotrypsin beads & 0.7829 & 0.4816 \\
\hline
\end{tabular}

MHC-AF preparations were incubated with or without trypsin or chymotrypsin coupled Sepharose $C L-4 B$ beads at $37^{\circ} \mathrm{C}$ for $2 \mathrm{~h}$. After the incubation chymotrypsin beads were removed from MHC-AF preparation by centrifugation. Augmentation of $\mathrm{MHC}$ I antigen expression in response to control and trypsin- or chymotrypsin-treated MHC-AF preparation $(20 \%(\mathrm{~V} / \mathrm{v}))$ was examined by cell ELISA technique described in 'Materials and Methods'.

were incubated at $37^{\circ} \mathrm{C}, 56^{\circ} \mathrm{C}$, or $72^{\circ} \mathrm{C}$ for $45 \mathrm{~min}$ and tested for their effects on class I MHC of YAC. Results in Figure 6 showed that MHC-AF preparations were stable at $37^{\circ} \mathrm{C}$ but lost $90-100 \%$ activity at $72^{\circ} \mathrm{C}$. Treatment at $56^{\circ} \mathrm{C}$ resulted in a partial loss of MHC-AF activity. These results indicated that $\mathrm{MHC}-\mathrm{AF}$ was deactivated at $72^{\circ} \mathrm{C}$.

\section{Sensitivity of MHC-AF to proteolytic enzyme}

In order to determine the susceptibility of MHC-AF to proteolytic enzymes, MHC-AF preparations were incubated with or without Sepharose CL-4B beads coupled to trypsin or chymotrypsin at $37^{\circ} \mathrm{C}$ for $2 \mathrm{~h}$. After the incubation, beads were removed by centrifugation and MHC-AF assay carried out. Results in Table 2 showed that MHCAF preparations treated with trypsin or chymotrypsin, lost their ability to augment the class I MHC expression on YAC. These expreiments indicated that MHC-AF activity resided in a molecule that was protein-like in nature.

\section{Purification of MHC-AF}

Since MLR supernatants were generated using culture medium containing fetal calf serum, protein concentration of MHC-AF preparations was very high, and number of irrelevant proteins was very large. In order to purify the MHC-AF activity, it was important to start with preparations

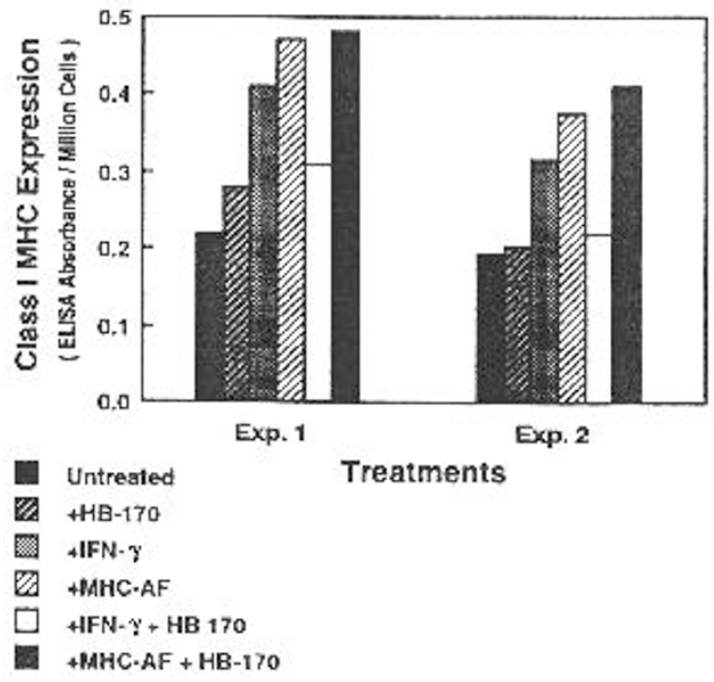

Figure 5. Failure of anti-murine IFN- $\gamma$ antibodies to neutralize the effect of MHC-AF on class I MHC expression of YAC. YAC cells were cultured alone or with $10 \%(\mathrm{v} / \mathrm{v})$ MHC-AF or $100 \mathrm{U} / \mathrm{ml}$ IFN- $\gamma$ for $48 \mathrm{~h}$. Preincubation of YAC cells with $50 \mu \mathrm{l}$ anti murine IFN- $\gamma$ antibody (secreted by ATCC hybridoma HB170) alone, or in presence of $10 \% \mathrm{v} / \mathrm{v}$

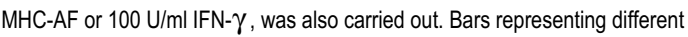
treatments are identified in the Figure. Results of two experiments have been shown.

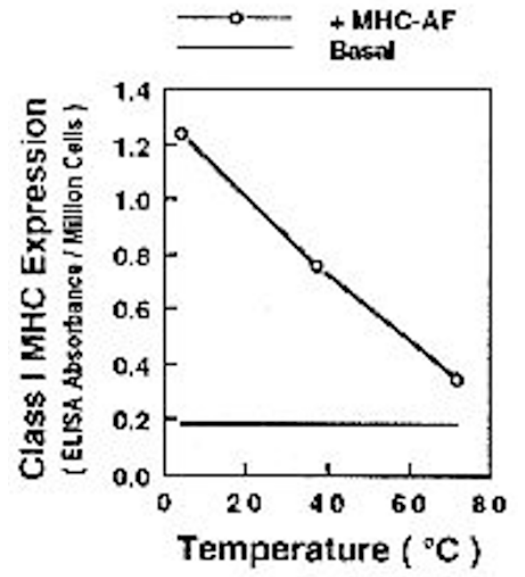

Figure 6. Effect of heat treatment on the biological activity of MHC-AF. Aliquots of MHC-AF were kept at $4^{\circ} \mathrm{C}, 37^{\circ} \mathrm{C}, 56^{\circ} \mathrm{C}$ and $72^{\circ} \mathrm{C}$ for $45 \mathrm{~min}$ each and then tested for MHC-AF activity at $20 \%$ (v/v) concentration, using cell ELISA technique. Results of one representative experiment are shown.

with least amount of irrelevant proteins. For this purpose, MHC-AF was generated in DCCM-2 serum free medium, processed upto Sephadex G-100 step as described above and further fractionated on reverse phase HPLC. DCCM-2 medium has previously been shown to be optimal for MHC-AF production of human MHC-AF (Raval et al., 1997). Figure 7 showed the elution profile 


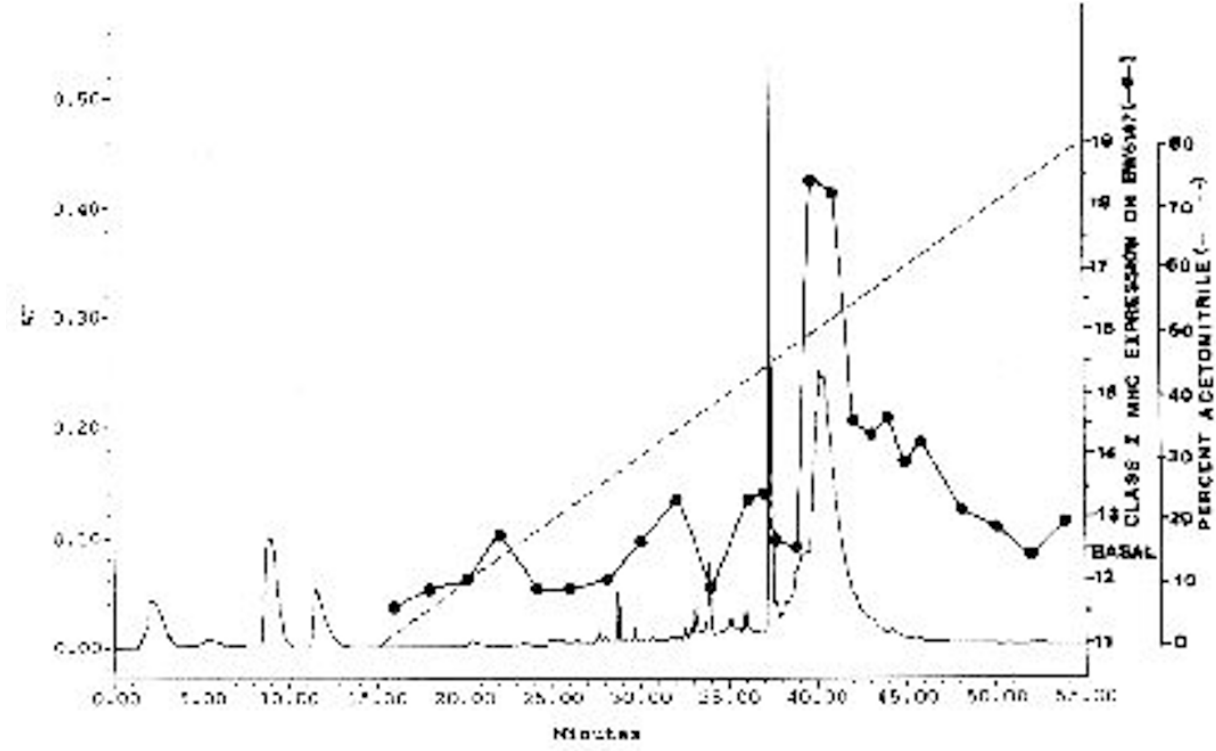

Figure 7. MHC-AF fractionation on Deltapak $\mathrm{C} 18$ reverse phase HPLC column. MHC-AF preyaration obtained after Sephadcx G-100 run was fractionated on a reverse phase HPLC column, run in $0.1 \%$ TFA, using an Acetonitrile gradient from 0 to $100 \%$ of $80 \%(\mathrm{v} / \mathrm{v})$. Elution profile of protein as measured at $280 \mathrm{~nm}$ is shown. The fractions were tested for MHC-AF activity on EL-4 cell line after lyophilization at $25 \%$ (v/v) as described in the 'Materials and Methods'. of MHC-AF on reverse phase column. MHC-AF eluted towards the end of the gradient whereas bulk of the proteins without biological activity eluted earlier. The fractions with MHC-AF activity were pooled and $25 \mu \mathrm{g}$ protein was subjected to $2 \mathrm{D}$ gel electrophoresis to check the heterogeneity of this preparation. $2 \mathrm{D} \mathrm{gel}$ profile of post RP HPLC MHC-AF preparation is given in Figure 8 and indicated the level of heterogeneity of MHC-AF preparation after the purification step.

\section{Discussion}

In the present study we have shown that MLRs of spleen cells from allogenic strains of mice, contain a soluble factor(s) which augments the expression of class I MHC molecules on some tumor cell lines. Expression of class I MHC antigens is also enhanced by IFN- $\gamma$ (Rosa and Fellows 1984), which is known to be released by activated $\mathrm{T}$ cells and NK cells. An obvious question therefore is whether MHC-AF activity could be attributed to IFN- $\gamma$. There are several lines of experimental evidence which indicate that MHC-AF is distinct from IFN (Saxena et al., 1988a, Puri et al., 1997). In the present study, with MLR supernatants, mouse MHC-AF preparations are routinely dialyzed against $\mathrm{pH} 2.0$ for $48 \mathrm{~h}$ at $4^{\circ} \mathrm{C}$, a treatment known to deactivate IFN- $\gamma$ (Farrar and Schreiber 1993). After this step, IFN activity was reduced to less than 0.1 $\mathrm{U} / \mathrm{ml}$ in mouse MHC-AF preparations. IFN- $\gamma$ at this dose level, has no effect on MHC I expression of YAC cells. By being acid stable, mouse MHC-AF appeared to be distinct from IFN- $\gamma$. We could also demonstrate that antiIFN- $\gamma$ monoclonal antibody, had no effect on the activity of MHC-AF. Taken together, these results indicate that MHC-AF is distinct from IFN- $\gamma$. We however, cannot rule out the possibilities that a degradation product of IFN- $\gamma$ or a truncated form of IFN- $\gamma$, lacking antiviral activity, but having class I MHC inducing activity and unreactive with anti-IFN- $\gamma$ antibodies, is responsible for MHC-AF activity.

Using gel chromatography on a calibrated Sephadex G-100 column, the molecular weight of MHC-AF was estimated to be $18 \mathrm{kDa}$. MHC-AF activity was destroyed at $72^{\circ} \mathrm{C}$ for $45 \mathrm{~min}$. This indicated, that MHC-AF could be a macromolecule denatured by heating. Further charac-terization indicated that MHC-AF activity was abolished by treatment with proteolytic enzymes, trypsin and chymo-trypsin. Therefore, MHC-AF activity appeared to reside in a protein molecule that contains basic as well as aromatic amino acids.

Cytokines are generally released into the culture media in extremely low concentrations ranging from few pg to few ng per $\mathrm{ml}$. We initially generated MHC-AF in culture

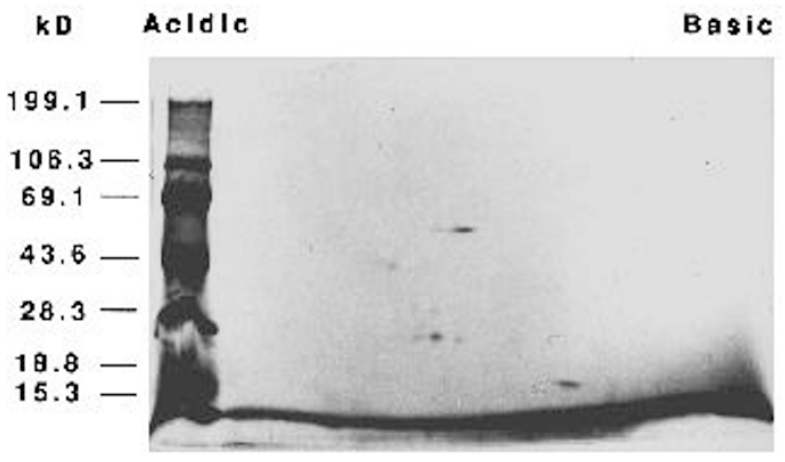

Figure 8. 2D-gel electrophorefsis of post HPLC active MHC-AF fractions $(25 \mu \mathrm{g}$ of pooled proteins), followed by silver staining. 
medium containing fetal calf serum which had a very high concentration of a very large number of proteins. We realized that purification of MHC-AF from serum containing medium would be very difficult, and therefore we shifted to a serum free culture medium. DCCM-2 medium we used for this purpose contained three defined proteins (Albumin, Transferrin and Insulin). MHC-AF prepared and purified from DCCM-2 medium up to reverse phase HPLC column still had protein heterogeneity as shown by 2D gel electrophoresis. Further purification, characterization and sequencing studies on MHC-AF will require to access sufficient quantities of MHC-AF. It would require suitable scale-up of production and purification operations, which have been standardized on a laboratory scale in the present study.

\section{Acknowledgment}

This project was supported by a DBT grant to RKS. NP received CSIR fellowship.

\section{References}

Benham, A., Tulp, A. and Neefjes, J. (1995) Synthesis and assembly of MHC peptide complexes. Immunology Today 16: 359

Bradford, M. M. (1976) A rapid and sensitive method for the quantitation of microgram quantities of protein utilizing the principle of protein dye binding. Anal. Biochem. 72: 248

Farrar, M. A. and Schreiber, R. D. (1993) The molecular cell biology of Interferon- $\gamma$ and its receptor. Annu. Rev. Immunol. 11: 571

Gidlund, M., Orn, A., Pattengale, P. K., Jansson, M., Wigzell, H. and Nilsson, K. (1981) Natural killer cells kill tumor cells at a given stage of differentiation. Nature 292: 848

Harel-Bellan, A., Quillet, A., Marchiol, C., DeMars, R., Tursz, T. and Fradelizi, D. (1986) Natural killer susceptibility of human cells may be regulated by genes in the HLA region of chromosome 6. Proc. Natl. Acad. Sci. USA 83: 5688

Karre, K., Ljunggren, H. C., Piontek, G. and Kiessling, R. (1986) Selective rejection of $\mathrm{H}-$ 2-deficient lymphoma variants suggests alternative immune defense strategy. Nature 319: 675

Kawano, Y. I., Taniguchi, K., Toshitani, A. and Nomoto, K. (1986) Synergistic defense system by cooperative natural effecters against metastasis of $\mathrm{B} 16$ melanoma cells in $\mathrm{H}$ 2 associated control: different behavior of $\mathrm{H}_{-} 2^{+}$and $\mathrm{H}-2{ }^{-}$cells in metastatic processes. J. Immunol. 136: 4729

Piontek, G. E., Taniguchi, K., Ljunggren, H. G., Gronberg, A., Kiessling, R., Klein, G. and Karre, K. (1985) Yac-I MHC class I variants reveal an association between decreased NK sensitivity and increased $\mathrm{H}-2$ expres-sion after IFN treatment or in vivo passage. J.Immunol. 135: 4281

Purl, N., Raval, A. and Saxena, R. K. (1997) Species specificity of a novel factor which augments the expression of MHC class I antigens on tumor cell lines. Exp. Mel. Med. 29: 129

Raval A., Purl, N. and Saxena, R. K. (1997) Generation of human class 1 major histocompatibility complex activating factor in serum free medium and its partial characterization. I. Biosci. 22: 59-68

Rei ter, Z., Fischer, D. C. and Rubinstein, M. (1988) The protective effect of interferon against natural killing activity is not mediated via the expres-sion of class I MHC antigens. Immunol. Lett. 17: 323

Rosa, F., and Fellows, M. (1984) The effect of gamma-interferon on MHC antigens. Immunol. Today 5: 261

Sarin, A., and Saxena, R. K. (1990) Quantitative estimation of major histo-compatibility antigens on liver tumor cells. Indian J. Exp. Biol. 28: 1017-1020

Saxena, R. K., Chrest, F. J. and Adler, W. H. (1989) Modulation of major histocompatibility antigens and inhibition of proliferative activity of YAC lymphoma cells by a Natural Killer-Lysis Resistance Inducing Factor (NK-LRIF). Nat. Immunol. Cell Growth Regul. 8: 197-208

Saxena, R. K., Saxena, Q. B. and Adler, W. H. (1988) Lectin induced cytotoxicity activity in spleen cells from young and old mice. Age related changes in types of effector cells, lymphokine production and response. Immunol. 64: 457

Saxena, R. K., Saxena, Q. B. and Adler, W. H. (1988) Properties and characterization of a rat spleen cell derived factor which induces resistance to NK cell lysis in YAC lymphoma cells. J. Immunol. 141: 1782

Stern, P., Gidlund, M., Orn, A. and Wigzell, H. (1980) Natural killer cells mediate lysis of embryogenic carcinoma cells lacking MHC. Nature 285: 341

Taniguchi, K., Petersson, M., Hoglund, P., Kiessling, R., Klein, G. and Karre, K. (1987) Interferon induces lung colonization by intravenously inoculated B16 melanoma cells in parallel with enhanced expression of class I histocompatibility complex antigens. Proc. Natl. Acad. Sci. USA 84: 3405

Zinkernagel, R. M. and Doherty, P. C. (1979) MHC-restricted cytotoxic T cells: studies on the biological role of polymorphic major transplantation antigens determining T-cell restriction specificity, function and responsive-ness. Adv. Immunol. 27: 51 